\title{
A Case of Membranous Glomerulonephropathy Associated with Takayasu's Arteritis
}

\author{
Ryo Koda $^{\mathrm{a}}$ Atsunori Yoshino ${ }^{\mathrm{a}}$ Yuji Imanishi $^{\mathrm{a}}$ Shinya Kawamoto ${ }^{\mathrm{a}}$ \\ Yoshihiko Ueda ${ }^{b}$ Junichiro James Kazama ${ }^{c}$ Ichiei Narita ${ }^{c}$ \\ Tetsuro Takeda ${ }^{a}$ \\ Departments of ${ }^{a}$ Nephrology and ${ }^{b}$ Pathology, Dokkyo Medical University Koshigaya \\ Hospital, Koshigaya, and 'Department of Clinical Nephrology and Rheumatology, Niigata \\ University Graduate School of Medical and Dental Sciences, Niigata, Japan
}

\section{Key Words}

Aortitis syndrome - Membranous glomerulonephropathy $\cdot$ Nephrotic syndrome $\cdot$ Systemic lupus erythematosus · Takayasu's arteritis

\begin{abstract}
Glomerulonephropathy is a rare complication of Takayasu's arteritis (TA). To date, most glomerulonephropathies associated with TA show the histological feature of mesangial proliferation. Membranous glomerulonephropathy (MG) is a form of glomerulonephropathy in which the mesangial proliferation is not conspicuous and its association with TA is extremely rare. A 54-year-old man was referred to our hospital due to progressive edema in the lower limbs and nephrotic range proteinuria. Five years previously, he underwent percutaneous angioplasty for left subclavian artery stenosis. Kidney biopsy revealed stage II MG. General examination including enhanced CT scan confirmed the presence of TA. He started oral prednisolone therapy at a dose of $40 \mathrm{mg}$ daily. The C-reactive protein level normalized 7 days after the prednisolone therapy. Three months later, proteinuria had remitted. Though the true relationship between MG and TA was not revealed in present case, considering the fact that complete remission of nephrotic syndrome occurred following the improvement of C-reactive protein level in response to steroid therapy, TA might be the secondary cause of MG. To our best knowledge, only two case reports described the association of MG and TA previously. Those two patients, however, also demonstrated the feature of systemic lupus erythematosus in addition to TA. This is the first case report that describes a patient who presented as MG associated with TA, but not complicated by systemic lupus erythematosus.
\end{abstract}


Koda et al.: A Case of Membranous Glomerulonephropathy Associated with Takayasu's Arteritis

\section{Introduction}

Takayasu's arteritis (TA) is an autoimmune disease that accompanies the active inflammation of relatively large-sized vessels like the aorta and its primary branches [1]. Information of the glomerulonephropathies associated with TA is limited. Most of the glomerulonephropathies associated with TA show the histological feature of mesangial proliferation, such as membranoproliferative glomerulonephritis [2], immunoglobulin A (IgA) nephropathy [3], focal segmental glomerulosclerosis [4] and crescentic glomerulonephritis [5]. Membranous glomerulonephropathy (MG) is a non-mesangial proliferative glomerulonephropathy, and its association with TA is extremely rare. To our best knowledge, only two case reports have described the association of MG with TA previously [6, 7]. Those two patients, however, also showed the feature of systemic lupus erythematosus (SLE). Herein, we report a case of MG with undiagnosed TA at the time of kidney biopsy. The criteria for SLE have not been met so far in this patient. This is the first case report that describes a patient who presented as MG associated with TA, but not complicated by SLE.

\section{Case Report}

A 54-year-old man with hyperlipidemia developed chance proteinuria during routine medical checkup. Within the next 4 months, edema in his lower limbs worsened with progression of hypoalbuminemia and increment in urinary protein excretion. He was referred to the nephrology department of our facility for the evaluation of proteinuria. Five years previously, he felt discomfort and coldness in his left hand and noted difficulty in detecting the peripheral pulse of the left radial artery. Further medical evaluation revealed left subclavian artery stenosis and he underwent percutaneous angioplasty with stent placement. This episode suggests the possibility of TA, however, the diagnosis was not made at that time.

Upon admission, his temperature was $36.8^{\circ} \mathrm{C}$, blood pressure $130 / 81 \mathrm{~mm} \mathrm{Hg}$ (right arm) and 128/83 mm Hg (left arm), and pulse 70 beats per minute with regular rhythm. Auscultation of the chest, lungs and abdomen was normal. Vascular bruit was audible on his neck bilaterally. The peripheral arteries (brachial, radial, popliteal and dorsal pedal) were palpable without laterality. Edema of the lower extremities was moderate. Skin rashes were not detected. Neurological findings were unremarkable. Laboratory data was as follows:

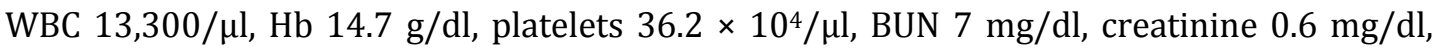
total protein $6.1 \mathrm{~g} / \mathrm{dl}(\alpha-14.7 \%, \alpha-215.5 \%, \beta 15.7 \%, \gamma 22.7 \%$ without monoclonal peak), albumin $1.85 \mathrm{~g} / \mathrm{dl}$, LDL-cholesterol $160 \mathrm{mg} / \mathrm{dl}$, fasting plasma glucose $96 \mathrm{mg} / \mathrm{dl}$, hemoglobin A1c 5.4\%, C-reactive protein (CRP) $1.23 \mathrm{mg} / \mathrm{dl}$ (normal 0.00-0.25), erythrocyte sedimentation rate $34 \mathrm{~mm} / \mathrm{h}$, immunoglobulin G (IgG) $870 \mathrm{mg} / \mathrm{dl}$, IgA $110 \mathrm{mg} / \mathrm{dl}$, immunoglobulin M (IgM) $35 \mathrm{mg} / \mathrm{dl}$, C3 $178.6 \mathrm{mg} / \mathrm{dl}$ (normal 65.0-135.0), and C4 $46.1 \mathrm{mg} / \mathrm{dl}$ (normal 13.035.0). Serology for antistreptolysin-0, hepatitis B, hepatitis C, anti-nuclear antibody, antidouble-stranded DNA antibody, and MPO and PR3 anti-neutrophil cytoplasmic antibody was negative. Cryoglobulin was not detected. Plasma renin activity was $2.6 \mathrm{ng} / \mathrm{ml} / \mathrm{h}$ (normal $0.3-5.4 \mathrm{ng} / \mathrm{ml} / \mathrm{h}$ ) and plasma aldosterone concentration was $17 \mathrm{pg} / \mathrm{ml}$ (normal 36-240). Urinalysis demonstrated protein (4+) without hematuria. Daily urinary protein excretion was 11.1 g. Ultrasonography showed morphologically normal kidneys. Familial history was unremarkable.

A kidney biopsy was performed (fig. 1, fig. 2); a total of 19 glomeruli were obtained from two pieces of specimen. Two glomeruli were globally sclerosed, the remaining 17 glomeruli 
Koda et al.: A Case of Membranous Glomerulonephropathy Associated with Takayasu's Arteritis

were hypertrophic. Intraglomerular hypercellularity, adhesion or crescent formation were not observed. Mesangial matrix proliferation was not conspicuous and mesangial cell proliferation was absent. The thickness of the glomerular basement membrane (GBM) was almost normal and typical spike formation or bubble-like appearance was not obvious. Tubular atrophy, fibrosis and lymphocyte infiltration were mild in the interstitial space. Hyalinosis and moderate thickening of the vessel wall was noted in the intralobular arteries and arterioles. Inflammatory changes on the vascular walls were not apparent. Under immunofluorescence microscopy, IgG was found in a granular pattern along the GBM. Analysis of IgG subclass revealed strong deposition of IgG1 and IgG4 as well as mild deposition of IgG2. Staining for IgA, IgM, C3, C4, C1q and fibrinogen were negative. Under electron microscopy, foot process effacement and extensive subepithelial electron dense deposits with the projection of basement membrane between adjacent immune deposits were broadly observed. Endothelial tubuloreticular inclusions were not observed. Stage II MG was diagnosed. Malignancy survey including chest X-ray, CT scan, testing the stool for blood, upper gastrointestinal endoscopy, measurement of tumor markers (CEA, CA19-9, PSA) demonstrated no significant abnormality. The patient's previous medical history of left subclavian artery stenosis strongly implied the presence of TA. After kidney biopsy, enhanced CT scan showed extensive thickening and enhancement of the vascular wall from the ascending portion to the abdominal aorta, resulting in narrowed and tortuous lumen. Involvement of the brachiocephalic trunk and bilateral vertebral arteries was detected, however, the bilateral renal arteries were unaffected. Considering the previous episode of subclavian artery stenosis, this patient met at least 3 of 6 American College of Rheumatology criteria (decreased brachial artery pulse, blood pressure difference $>10 \mathrm{~mm} \mathrm{Hg}$ and arteriogram abnormality) for the classification of TA [8]. TA was diagnosed and oral prednisolone (PSL) was initiated at a dose of $40 \mathrm{mg} /$ day. Seven days after the PSL therapy, the CRP level had decreased to normal. Three month later, the urinary protein to creatinine ratio became $<0.15 \mathrm{~g} / \mathrm{gCr}$. Enhanced CT scan 1 year later showed improvement of wall thickening in the entire aorta. PSL was gradually tapered to $5 \mathrm{mg}$ daily and he remains free from relapse of both MG and TA (fig. 3).

\section{Discussion}

TA is characterized by the active inflammation of relatively large-sized vessels like aorta and its primary branches [1]. This disease has a sexual, racial and genetic predisposition. Kimura et al. [9] demonstrated the association of HLA-B52 and HLA-B39.2 with TA in the Japanese population. Major histocompatibility class I chain-related A, Th17 cells, NK cells or inflammatory cytokines like VEGF and IL-6 have been clarified to be involved in the pathogenesis of TA [10], however, the exact pathogenesis remains to be elucidated.

Renal complication in TA is conventionally divided into two categories: renovascular disease and glomerular disease. Renal artery stenosis can occur as a consequence of arterial wall thickening due to atherosclerosis secondary to prolonged inflammation. Decreased blood supply into the kidney sometimes results in inappropriate activation of the reninangiotensin aldosterone system, leading to uncontrollable hypertension. In the present case, abdominal three-dimensional CT angiography showed no significant stenosis in the bilateral renal arteries, and none of the kidneys were atrophic (fig. 4). Histologically, narrowing of the lumen of the arterioles and intralobular arteries was mild, and in the vascular walls inflammatory changes were not evident. Two out of 19 observable glomeruli were globally sclerosed, however, the other glomeruli were relatively swollen rather than 
Koda et al.: A Case of Membranous Glomerulonephropathy Associated with Takayasu's Arteritis

collapsed, indicating that the blood supply into the patient's kidneys was maintained. His blood pressure was within normal range, and plasma renin activity and plasma aldosterone concentration was not elevated. Therefore, renovascular involvement by TA was unlikely in the present case.

With respect to glomerulonephropathy associated with TA, only a few clinical reports are currently available [2-7]. Mesangial proliferative glomerulonephropathy is the predominant histological feature among them. de Pablo et al. [11] performed retrospective pathological kidney investigation in 25 autopsy cases of TA. Their study showed that 10 out of 25 cases $(40 \%)$ had diffuse mesangial proliferative glomerulonephritis, while $4(16 \%)$ cases had other forms of glomerulonephritis (focal segmental glomerulosclerosis, global and focal glomerulosclerosis, segmental necrotizing glomerulonephritis and amyloidosis). To date, only two case reports have described MG associated with TA $[6,7]$. Notably, the patients in these reports were also complicated by SLE [6] or lupus-like glomerulonephropathy [7] (table 1). Complication of TA by SLE is also rare, only approximately 20 cases having been reported to date [12]. The patient with both TA and SLE reported by Kitazawa et al. [6] showed intramembranous microspheres and epithelial cytoplasmic processes on the GBM, the findings of so-called podocytic infolding glomerulopathy (PIG). PIG is a relatively new disease entity proposed in 2008 and sometimes associated with lupus nephritis class V [13]. In the present case, however, the findings of PIG were not observed in the GBM. TA tends to develop an average of 9.6 years before SLE [12]. Although the criteria for SLE have not been met so far in the present case, the possibility of the development of SLE in the future should be kept in mind.

In Japan, approximately $80 \%$ of MG in adults are reported to be 'idiopathic', whereas $20 \%$ of them have secondary causes (hepatitis B virus infection, autoimmune disease like SLE, malignancies, certain medications, IgG4-related disease, hematopoietic cell transplantation and graft-versus-host disease). It is usually difficult to determine a direct causal relationship between MG and assumed secondary causes. Beck et al. [14] demonstrated that antibodies against phospholipase A2 receptor are detectable in patients with idiopathic $M G$, but not in patients with secondary form or in healthy individuals. Measurement for antibodies against phospholipase A2 receptor seems useful to determine whether MG is idiopathic or not, however, this procedure remains highly experimental and currently unavailable in routine clinical practice in Japan. Several immunohistochemical analyses for the deposition of IgG subclasses in glomerular disease have been performed. In MG, predominance of IgG1 and IgG4 suggests the idiopathic form, whereas predominance of IgG1 and IgG2 suggests the malignancy-associated form and predominance of IgG1 and IgG3 lupus nephritis [15]. In the present case, analysis of IgG subclass revealed (2+) positivity for IgG1 and IgG4 and (1+) positivity for IgG2 along the GBM with granular pattern. General physical examination, measurement of tumor markers, enhanced CT, test for stool blood and endoscopic survey showed no evidence of underlying malignancy. In terms of IgG subclass analysis, this patient is classified as 'idiopathic' MG. However, it has been reported that IgG subclass analysis does not have sufficient specificity for discriminating the idiopathic from the secondary form of MG. In the present case, the direct causal relationship between MG and TA is unrevealed. He had a history of left subclavian artery stenosis 5 years before, implying that TA had preceded the onset of MG at least 5 years. Considering the chronology of onset of TA and MG, and the fact that proteinuria had completely disappeared after the remission of TA by steroid therapy, TA might be the secondary cause of MG in the present case.

In conclusion, to our best knowledge, this is the first case report that describes MG associated with TA not complicated by SLE. Although mesangial proliferative glomerulo- 


\begin{tabular}{l|l}
\hline DOI: $10.1159 / 000360850$ & $\begin{array}{l}\text { C 2014 S. Karger AG, Basel } \\
\text { www.karger.com/cru }\end{array}$ \\
\hline
\end{tabular}

Koda et al.: A Case of Membranous Glomerulonephropathy Associated with Takayasu's Arteritis

nephropathy has been predominantly reported, MG, a non-mesangial proliferative glomerulonephropathy, could be manifested with TA. Since information is extremely limited, further reports are needed to shed light on glomerular disease associated with TA.

\section{Acknowledgements}

The authors are truly indebted to T. Okamura and M. Jinnai for their technical assistance.

\section{Disclosure Statement}

The authors declare that there are no conflicts of interest.

\section{References}

1 Alibaz-Oner F, Aydin SZ, Direskeneli H: Advances in the diagnosis, assessment and outcome of Takayasu's arteritis. Clin Rheumatol 2013;32:541-546.

-2 Kuroda T, Ueno M, Sato H, Murakami S, Sakatsume M, Nishi S, Nakano M, Gejyo F: A case of Takayasu arteritis complicated with glomerulonephropathy mimicking membranoproliferative glomerulonephritis: a case report and review of the literature. Rheumatol Int 2006;27:103-107.

-3 Cavatorta F, Campisi S, Trabassi E, Zollo A, Salvidio G: IgA nephropathy associated with Takayasu's arteritis: report of a case and review of the literature. Am J Nephrol 1995;15:165-167.

4 Tiryaki O, Buyukhatipoglu H, Onat AM, Kervancioglu S, Cologlu S, Usalan C: Takayasu arteritis: association with focal segmental glomerulosclerosis. Clin Rheumatol 2007;26:609-611.

5 Hellmann DB, Hardy K, Lindenfeld S, Ring E: Takayasu's arteritis associated with crescentic glomerulonephritis. Arthritis Rheum 1987;30:451-454.

-6 Kitazawa K, Joh K, Akizawa T: A case of lupus nephritis coexisting with podocytic infolding associated with Takayasu's arteritis. Clin Exp Nephrol 2008;12:462-466.

7 Nakashima A, Miyazaki R, Koni I, Tsugawa Y, Iwainaka Y, Kawano M, Tofuku Y, Takeda R: A case of aortitis syndrome (Takayasu's arteritis) associated with glomerulonephropathy mimicking lupus membranous glomerulonephropathy (in Japanese). Nihon Jinzo Gakkai Shi 1988;30:233-238.

-8 Arend WP, Michel BA, Bloch DA, Hunder GG, Calabrese LH, Edworthy SM, Fauci AS, Leavitt RY, Lie JT, Lightfoot RW Jr: The American College of Rheumatology 1990 criteria for the classification of Takayasu arteritis. Arthritis Rheum 1990;33:1129-1134.

-9 Kimura A, Kitamura H, Date Y, Numano F: Comprehensive analysis of HLA genes in Takayasu arteritis in Japan. Int J Cardiol 1996;54(suppl):S61-S69.

10 Weyand CM, Goronzy JJ: Medium- and large-vessel vasculitis. N Engl J Med 2003;349:160-169.

11 de Pablo P, García-Torres R, Uribe N, Ramón G, Nava A, Silveira LH, Amezcua-Guerra LM, Martínez-Lavín M, Pineda C: Kidney involvement in Takayasu arteritis. Clin Exp Rheumatol 2007;25(1 suppl 44):S10-S14.

12 Igarashi T, Nagaoka S, Matsunaga K, Katoh K, Ishigatsubo Y, Tani K, Okubo T, Lie JT: Aortitis syndrome (Takayasu's arteritis) associated with systemic lupus erythematosus. J Rheumatol 1989;16:1579-1583.

13 Joh K, Taguchi T, Shigematsu H, Kobayashi Y, Sato H, Nishi S, Katafuchi R, Nomura S, Fujigaki Y, Utsunomiya Y, Sugiyama H, Saito T, Makino H: Proposal of podocytic infolding glomerulopathy as a new disease entity: a review of 25 cases from nationwide research in Japan. Clin Exp Nephrol 2008;12:421-431.

14 Beck LH Jr, Bonegio RG, Lambeau G, Beck DM, Powell DW, Cummins TD, Klein JB, Salant DJ: M-type phospholipase A2 receptor as target antigen in idiopathic membranous nephropathy. N Engl J Med 2009;361:11-21.

15 Haas M: IgG subclass deposits in glomeruli of lupus and nonlupus membranous nephropathies. Am J Kidney Dis 1994;23:358-364. 
Koda et al.: A Case of Membranous Glomerulonephropathy Associated with Takayasu's Arteritis

Table 1. Three cases of MG associated with TA

\begin{tabular}{|c|c|c|c|}
\hline & Case 1 & Case 2 & Case 3 \\
\hline Age/gender & 61 years/F & 47 years $/ F$ & 54 years/M \\
\hline $\begin{array}{l}\text { Age at onset } \\
\text { of TA }\end{array}$ & 38 years & 47 years & $45-50$ years \\
\hline $\begin{array}{l}\text { Affected } \\
\text { arteries }\end{array}$ & $\begin{array}{l}\text { left subclavian artery, } \\
\text { left vertebral artery }\end{array}$ & $\begin{array}{l}\text { left pulmonary artery, } \\
\text { abdominal aorta, right } \\
\text { renal artery }\end{array}$ & $\begin{array}{l}\text { left subclavian artery, } \\
\text { ascending to abdominal } \\
\text { aorta, brachiocephalic } \\
\text { trunk and bilateral } \\
\text { vertebral arteries }\end{array}$ \\
\hline $\begin{array}{l}\text { Compli- } \\
\text { cation }\end{array}$ & $\begin{array}{l}\text { SLE [anemia, leukopenia, } \\
\text { lymphopenia, ANA (+), } \\
\text { hypocomplementemia, } \\
\text { anti-DNA antibody (+), } \\
\text { urinary protein }(3+) \text {, lupus } \\
\text { band test }(+)]\end{array}$ & $\begin{array}{l}\text { SLE suspicion } \\
\text { [ANA (+), anti-DNA } \\
\text { antibody } 39.7 \mathrm{U} / \mathrm{ml}, \\
\text { urinary protein }(3+)]\end{array}$ & dyslipidemia \\
\hline $\begin{array}{l}\text { Kidney } \\
\text { function }\end{array}$ & $\begin{array}{l}\text { sCr: normal*; } \\
\text { CCR: } 38.6 \mathrm{ml} / \mathrm{min}\end{array}$ & sCr: $0.8 \mathrm{mg} / \mathrm{dl}$ & sCr: $0.6 \mathrm{mg} / \mathrm{dl}$ \\
\hline $\begin{array}{l}\text { Urinary } \\
\text { protein }\end{array}$ & $1.7 \mathrm{~g} /$ day & $(3+)$ & $11.1 \mathrm{~g} /$ day \\
\hline Hematuria & $(-)$ & $(+/-)$ & $(-)$ \\
\hline CRP & high* & $<1.0 \mathrm{mg} / \mathrm{dl}$ & $1.23 \mathrm{mg} / \mathrm{dl}$ \\
\hline ESR & elevated* & $58 \mathrm{~mm} / \mathrm{h}$ & $109 \mathrm{~mm} / \mathrm{h}$ \\
\hline $\begin{array}{l}\text { Kidney } \\
\text { biopsy }\end{array}$ & $\begin{array}{l}\text { class II lupus nephritis } \\
\text { with podocytic infolding } \\
\text { associated with TA }\end{array}$ & $\begin{array}{l}\text { glomerulonephropathy } \\
\text { mimicking lupus mem- } \\
\text { branous nephropathy }\end{array}$ & MG (stage II) \\
\hline $\begin{array}{l}\text { Light } \\
\text { microscopy }\end{array}$ & $\begin{array}{l}\text { GS: }{ }^{* *} \text {, spike }(-) \text {, } \\
\text { bubble-like appearance } \\
\text { in GBM }(+) \text {, mesangial } \\
\text { matrix and cell } \\
\text { proliferation }(+)\end{array}$ & $\begin{array}{l}\text { GS: } 3 / 23 \text {, spike }(+) \text {, } \\
\text { mesangial matrix and } \\
\text { cell proliferation }(+)\end{array}$ & $\begin{array}{l}\text { GS: } 2 / 19 \text {, spike }(-) \text {, slight } \\
\text { increase in mesangial } \\
\text { matrix, mesangial cell } \\
\text { proliferation }(-)\end{array}$ \\
\hline $\begin{array}{l}\text { Immuno- } \\
\text { fluorescence }\end{array}$ & $\begin{array}{l}\text { granular deposits of IgG, } \\
\text { IgM, C1q in capillary and } \\
\text { mesangial lesion, IgG } \\
\text { subclass: not assessed }\end{array}$ & $\begin{array}{l}\text { granular deposits of } \\
\text { IgG, IgA, IgM, C1q, C3 in } \\
\text { the capillary wall and } \\
\text { mesangial lesion, IgG } \\
\text { subclass: not assessed }\end{array}$ & $\begin{array}{l}\text { granular deposits of IgG } \\
\text { in capillary wall, IgG } \\
\text { subclass: IgG1 }(2+), \text { IgG2 } \\
(+) \text {, IgG3 (-), IgG4 }(2+)\end{array}$ \\
\hline $\begin{array}{l}\text { Electron } \\
\text { microscopy }\end{array}$ & $\begin{array}{l}\text { subepithelial, intra- } \\
\text { membranous and } \\
\text { mesangial deposits } \\
\text { (podocyte infolding } \\
\text { glomerulopathy) }\end{array}$ & $\begin{array}{l}\text { subepithelial and } \\
\text { mesangial deposits }\end{array}$ & subepithelial deposits \\
\hline Treatment & PSL $40 \mathrm{mg}+$ CyA $100 \mathrm{mg}$ & $* *$ & PSL $40 \mathrm{mg}$ \\
\hline Course & $\begin{array}{l}\text { urinary protein } \\
<1.0 \mathrm{~g} / \text { day }\end{array}$ & $* *$ & $\begin{array}{l}\text { urinary protein (-), } \\
\mathrm{CRP}<1.0 \mathrm{mg} / \mathrm{dl}\end{array}$ \\
\hline Reference & Kitazawa et al. [6] & Nakashima et al. [7] & present case \\
\hline
\end{tabular}

ANA = Anti-nuclear antibody; $\mathrm{CCR}=$ creatinine clearance rate; $\mathrm{CyA}=$ cyclosporine;

$\mathrm{ESR}=$ erythrocyte sedimentation rate; $\mathrm{GS}$ = glomerulosclerosis; $\mathrm{SCr}=$ serum creatinine .

*Value not described. ${ }^{* *}$ Not described. 


\section{Case Reports in \\ Nephrology and Urology}

\begin{tabular}{l|l}
\hline Case Rep Nephrol Urol 2014;4:60-69 \\
\hline DOI: 10.1159/000360850 & $\begin{array}{l}\text { @ 2014 S. Karger AG, Basel } \\
\text { www.karger.com/cru }\end{array}$ \\
\hline
\end{tabular}

Koda et al.: A Case of Membranous Glomerulonephropathy Associated with Takayasu's Arteritis

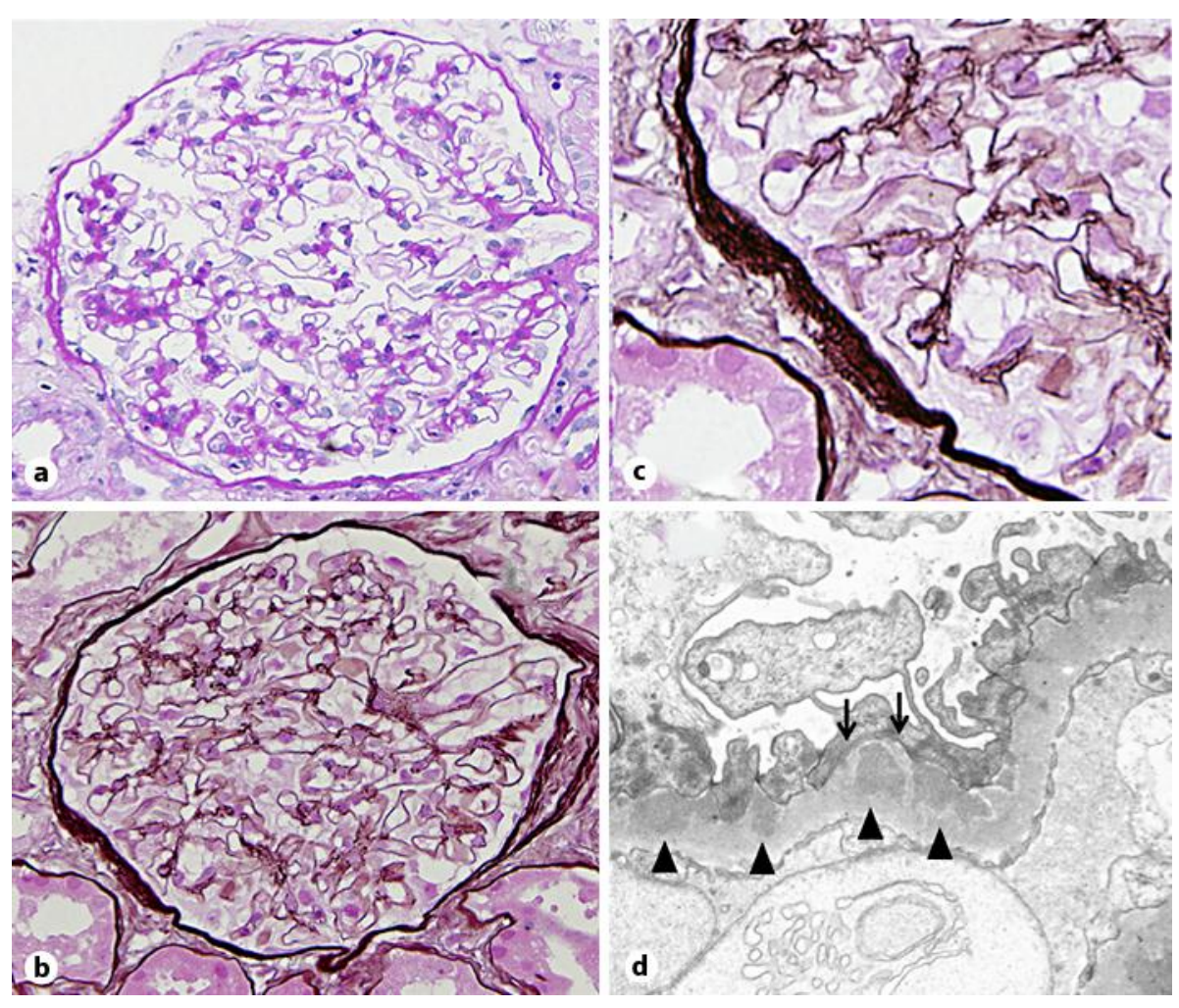

Fig. 1. Microscopic findings. a Periodic acid-Schiff staining. $\times 200$. The glomeruli are hypertrophic, but thickening of the GBM is not apparent. A mild increase in mesangial matrix is occasionally noted, but mesangial cell proliferation is not obvious. $\mathbf{b}$ Periodic acid methenamine silver staining, $\times 200$. c Magnified view of $\mathbf{b}, \times 400$. Spike formation or bubble-like appearance on the capillary walls is not apparent. d Electron microscopic findings. Irregular thickening of the GBM with diffuse subepithelial immune deposits (arrowheads) is observed along the entire capillary wall. Projection of the GBM (arrows) is noted between adjacent immune deposits, compatible with stage II MG. Intramembranous and subendothelial immune deposits are not apparent. 
Case Reports in

Nephrology and

Urology
Case Rep Nephrol Urol 2014;4:60-69

DOI: $10.1159 / 000360850$

Koda et al.: A Case of Membranous Glomerulonephropathy Associated with Takayasu's Arteritis

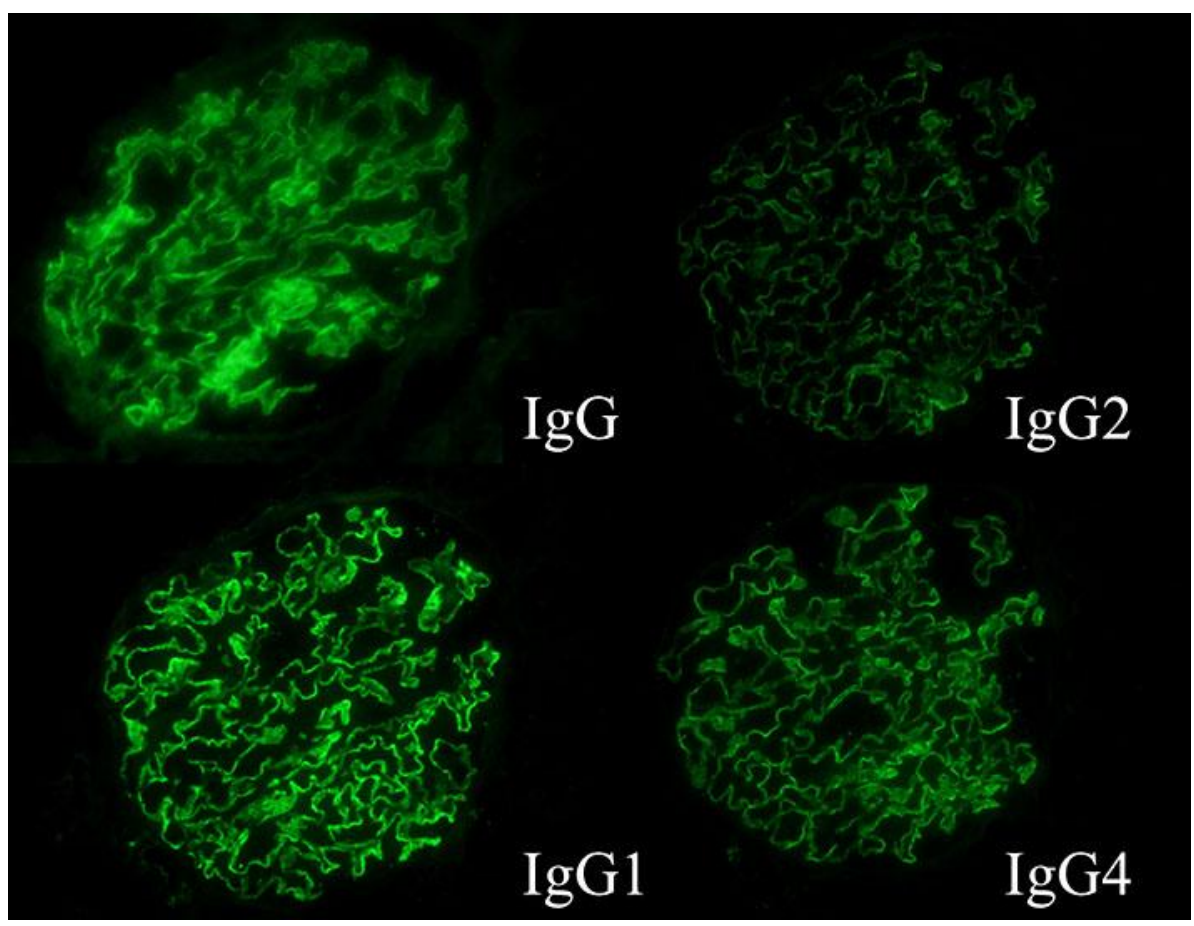

Fig. 2. Immunofluorescence. Diffuse, granular patterns of IgG deposits are observed along the capillaries. Staining intensity of IgG1 and IgG4 is predominant, whereas IgG2 shows weak intensity. Deposition of IgG3 was negative (not shown). 
Koda et al.: A Case of Membranous Glomerulonephropathy Associated with Takayasu's Arteritis

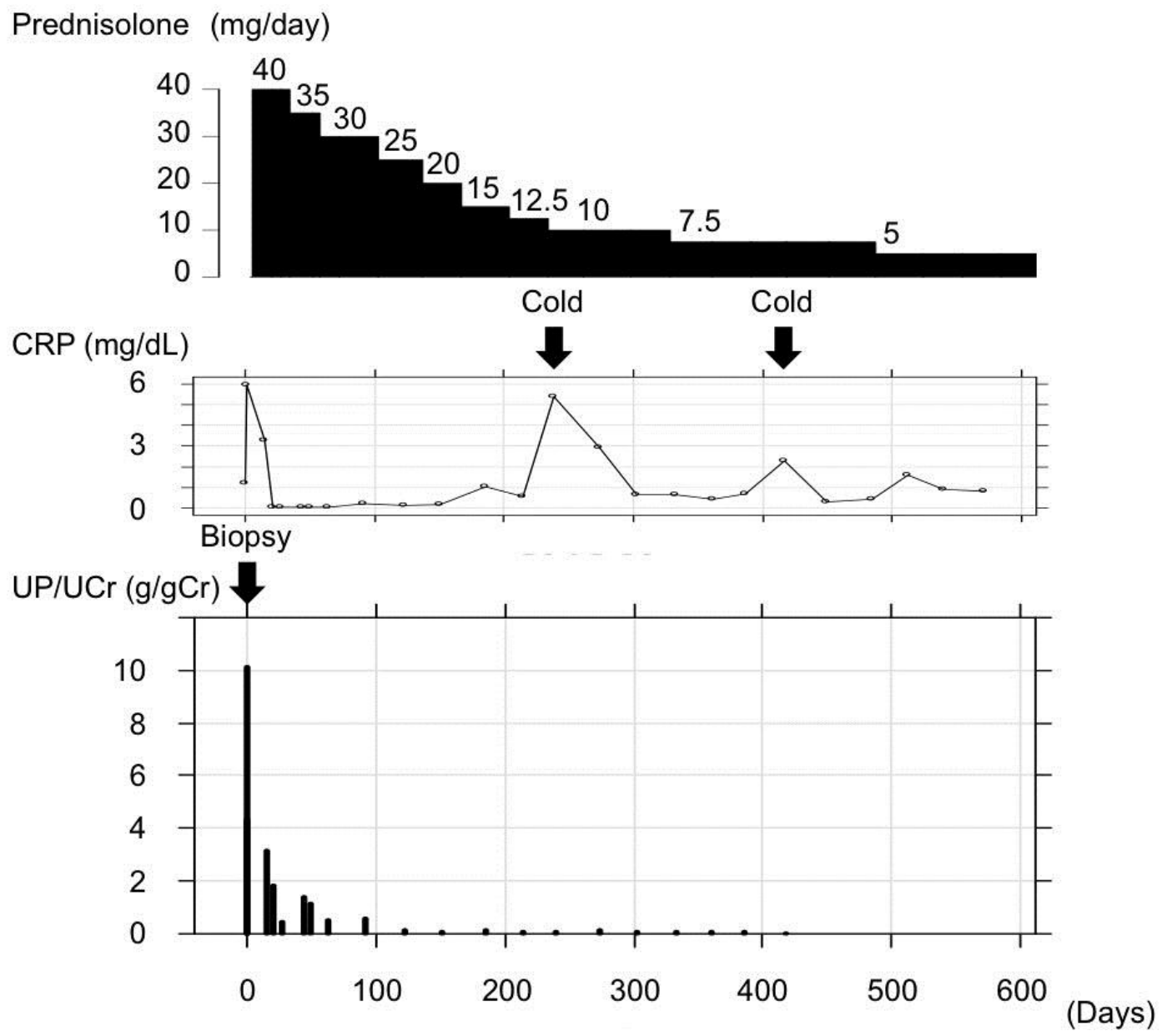

Fig. 3. Clinical course. Percutaneous angioplasty for left subclavian artery stenosis was performed 5 years previously. Proteinuria was detected 4 months before admission. Kidney biopsy showed stage II MG and three-dimensional CT angiography confirmed the presence of TA. Oral PSL was initiated at a dose of $40 \mathrm{mg}$ daily. CRP was normalized 7 days after the initiation of PSL therapy. Proteinuria decreased gradually. Three month later, proteinuria became $<0.15 \mathrm{~g} / \mathrm{gCr}$. Eighteen months later, nephrotic syndrome and TA remain remitted with $5 \mathrm{mg}$ PSL daily. During the clinical course, CRP increased twice due to colds. $\mathrm{UP} / \mathrm{UCr}=$ Urinary protein to creatinine ratio. 


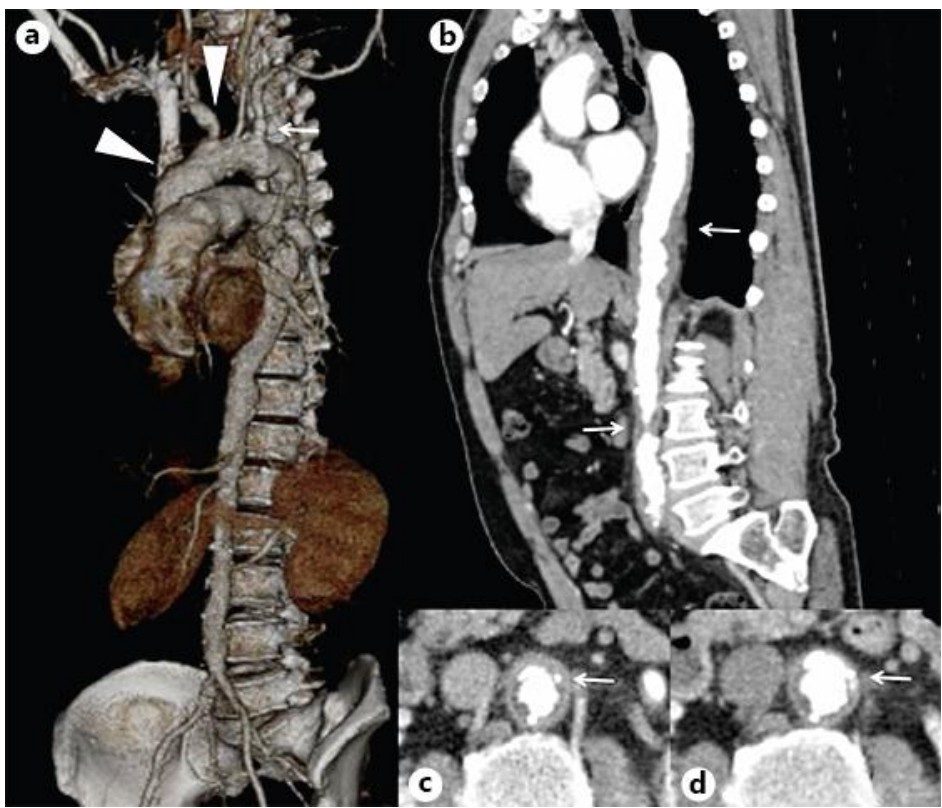

Fig. 4. a Three-dimensional CT angiography showed diffuse stenosis in the aortic arch and primary branches (arrowheads). A stent was placed in the proximal portion of the left subclavian artery (arrow). b A sagittal CT scan showed a thickened wall along the thoracic aorta (arrows). c CT scan before treatment. The abdominal aorta showed diffuse wall thickening (arrow). d One year after the PSL therapy, wall thickening was improved (arrow). 